How to cite: Alvarado, L. E., Aragón, R. R. \& Bretones, F. D. (2020). Teachers' Attitudes Towards the Introduction of ICT in Ecuadorian Public Schools. TechTrends, 64. doi: 10.1007/s11528-020-00483-7.

\title{
Teachers' Attitudes Towards the Introduction of ICT in Ecuadorian Public Schools
}

\author{
Luis E. Alvarado
}

School of Psychology, University of Guayaquil (Ecuador)

Rebeca R. Aragón

School of Labor Relations and Human Resources, University of Granada (Spain)

Francisco D. Bretones ${ }^{1}$

School of Labor Relations and Human Resources, University of Granada (Spain)

\begin{abstract}
This article focus on the attitudes of teachers about the implementation of information and communication technologies (ICT) in Ecuadorian schools. While the advantages of ICT in education are well researched, much less is known about the attitudes of teachers towards them. This article provides a qualitative interpretative analysis of the opinions and attitudes of 56 teachers in Ecuador. The produced results acknowledged that implementation of ICT in schools is a difficult task due to a lack of materials and resources, high organisational and social demands perceived by teachers, competition caused by younger teachers and students, and job and personal insecurity. Finally, this article suggests some aspects that should be considered and some actions that should be taken in order to minimize these negative aspects.
\end{abstract}

\section{Keywords}

Computer attitudes; Developing country; Organizational demands; Public school teacher; Socio-technical context; Teaching resources; Technological literacy.

\footnotetext{
${ }^{1}$ Corresponding author: Francisco Díaz Bretones. Universidad de Granada. Facultad de Relaciones Laborales y Recursos Humanos. Edificio San Jeronimo. 18071 Granada (Spain). fdiazb@ugr.es
} 
How to cite: Alvarado, L. E., Aragón, R. R. \& Bretones, F. D. (2020). Teachers' Attitudes Towards the Introduction of ICT in Ecuadorian Public Schools. TechTrends, 64. doi: 10.1007/s11528-020-00483-7.

\section{Introduction}

The introduction of technological elements in education during the last decades has brought clear advantages by providing new learning opportunities based on digital creativity and collaborative communication (Livingstone 2012). Information and Communication Technologies (ICT) have produced big changes in the learning process (Lawrence \& Tar 2018), while it is also evident, the scarce research on the development of cognitive skills as a fundamental objective of technological education (Buckley, Seery, Canty, \& Gumaelius 2018).

However, it is undeniable that any process brings benefits and opportunities, but also inequalities and injustices. This is especially obvious in the case of developing countries where the available resources are allocated limitedly and unequally among their members, which creates a self-perpetuating cycle of social and economic inequality (Eubanks 2007; Torraco 2018). All these factors contribute to increase more conflict situations where schools and teachers are affected, which causes a stressful source of working conditions for them.

Thus, although the introduction of technology in schools has great advantages for teachers' professional performance (Kopcha 2012; Ottenbreit-Leftwich, Glazewski, Newby, \& Ertmer 2010), it also produces changes that pose new challenges and conflicts to take into account that should be considered prospectively (Martin, Diaz, Sancristobal, Gil, Castro, \& Peire 2011; Otterborn, Schönborn, \& Hultén 2018).

The spillover of work time and environment on staff and its consequences for work-life balance (Currie \& Eveline 2011; Harris, Harris, Carlson, \& Carlson 2015), the frustration due to the complexity of new techonology, the threat to job security and the fear of technological uncertainty (Tarafdar, Tu, Ragu-Nathan, \& Ragu-Nathan 2007), the increase in competition (Jena 2015), the spread of work culture outside school (Ragu-Nathan, Tarafdar, Ragu-Nathan, 
How to cite: Alvarado, L. E., Aragón, R. R. \& Bretones, F. D. (2020). Teachers' Attitudes Towards the Introduction of ICT in Ecuadorian Public Schools. TechTrends, 64. doi: 10.1007/s11528-020-00483-7.

\& Tu 2008) and the stress caused by the use of technology (Al-fudail \& Mellar 2008; Joo, Lim, \& Kim 2016) are, among others, some of the negative effects that the introduction of ICTs in schools has on teachers.

Taking this into account, Selwyn (2010) considers that the relationships between education and technology are controversial and proposes a critical approach to go further than just wondering about if a particular technology works in a technical way. For this reason different authors (Barak 2016; Perrotta 2017; Saunders 2013) mention the need to include other emotional and social elements of teachers when implementing ICT in education.

Thus, the implementation of technology in schools cannot only focus on the effectiveness of technical skills (Paraskeva, Bouta, \& Papagianni 2008), but other social and cognitive aspects such as expectations, beliefs and attitudes of teachers (González-Sanmamed, Sangrà, \& Muñoz-Carril 2017; Tondeur, van Braak, Ertmer, \& Ottenbreit-Leftwich 2016), as well as their engagement and active training (Fernández-Cruz \& Fernández-Díaz 2016) should be considered.

The frequent adaptation to technological changes will generate an increase in demands and personal and professional resources of teachers, increasing the complexity and overload of their activity which will result in resistance and defensive attitudes towards these changes (Ertmer, Ottenbreit-Leftwich, Sadik, Sendurur, \& Sendurur 2012; Kotrlik \& Redmann 2005; Yu, Lin, \& Liao 2017).

New ICTs generate a work overload for teachers, such as meeting an increasing demand for documents, more common virtual meetings, more usual online communication with parents and students, or participation in school development projects, which directly affects their rest and recovery time (Ballet \& Kelchtermans 2008; Lindqvist \& Nordanger 2006). 
How to cite: Alvarado, L. E., Aragón, R. R. \& Bretones, F. D. (2020). Teachers' Attitudes Towards the Introduction of ICT in Ecuadorian Public Schools. TechTrends, 64. doi: 10.1007/s11528-020-00483-7.

In addition, technification may in some cases lead to the intensification of the pace of work, with higher levels of interruptions (Chesley 2014). For some authors (Addas \& Pinsonneault 2015) these constant interruptions not only affect task performance, but they also increase cognitive overload and wrong decision-making. Technological interruptions (such as messages, emails, etc.) as well as intrusive requests for information-may lead to a decrease in production, misunderstandings and oversights. Moreover, externally imposed classroom interruptions encroach upon the domain of the learning environment (Leonard 2001). Other authors suggest that interruptions should be perceived as interactive processes of constant connectivity (Wajcman \& Rose 2011), so they should not be considered distractors or eliminated, but the relationship with them should be restructured and managed.

All these processes will produce an increase in teachers' levels of stress (Joo et al. 2016; Yu et al. 2017) generating different negative emotions such as technophobia that manisfests itself as rage, depression and severe states of anxiety towards technology (Rosen \& Weil 1995; Tsang \& Kwong 2017; Wilfong 2006) with negative consequences for teachers' job satisfaction, organizational commitment and continuance (Bretones, González-González, Francés-Gómez, \& González 2017; Ragu-Nathan et al. 2008).

For all these reasons, the main objective of this study has been to understand teachers' attitudes, that is, their opinions, emotions and feelings regarding working conditions based on the integration of technology in their work activity. To achieve this goal, we ask ourselves the following research question:

What are the attitudes, working conditions and labor demands of teachers upon the implementation of ICT in the classroom? 
How to cite: Alvarado, L. E., Aragón, R. R. \& Bretones, F. D. (2020). Teachers' Attitudes Towards the Introduction of ICT in Ecuadorian Public Schools. TechTrends, 64. doi: 10.1007/s11528-020-00483-7.

\section{Material and Methods}

In order to achieve this objective, several in-deep interviews have been conducted in a sample of 56 teachers (38 women and 18 men) from several elementary, secondary and vocational public schools ${ }^{2}$ in the city of Guayaquil (Ecuador) to characterize their attitudes towards the introduction of ICT in schools, describe job demands and assess its emotional implications and its consequences.

We consider that in-deep interviews are the most appropriate method to study the impact of the implementation of ICT in education, since it provides people with maximum space and control to tell their perceptions, opinions and experiences. Also, this qualitative methodology is especially useful in educational research when analyzing and understanding the links between processes and results (Hammersley 2000; Shaw 2003).

A more detailed description of the participants of this study can be seen in Table 1:

$\begin{array}{ll}\text { Participant } & \text { Sex } \\ 1 & \text { Woman } \\ 2 & \text { Woman } \\ 3 & \text { Woman } \\ 4 & \text { Woman } \\ 5 & \text { Man } \\ 6 & \text { Woman } \\ 7 & \text { Man } \\ 8 & \text { Woman } \\ 9 & \text { Woman } \\ 10 & \text { Woman } \\ 11 & \text { Woman } \\ 12 & \text { Woman } \\ 13 & \text { Woman } \\ 14 & \text { Woman } \\ 15 & \text { Man }\end{array}$

Table 1: Description of the study participants

Role School

Vocational teacher Paraíso universal

Elementary teacher 5 de Junio

Vocational teacher Futuro del Saber

Vocational teacher Manuel Wolf Herrera

Elementary teacher Agustín Castro Espinoza

Elementary teacher Manuel Sandoval Simball

Secondary teacher Alonso de Illescas

Vocational teacher Monseñor Leonidas Proaño

Secondary teacher Dr. Alberto Cabezas

Elementary teacher María Mercedes Cleofe Silva

Elementary teacher Néstor Campuzano Mendoza

Elementary teacher Arnulfo Jaramillo sierra

Elementary teacher Blanca García Plaza de Arias

Elementary teacher Enrique Ibáñez Mora

Elementary teacher Agustín Castro Espinoza

\footnotetext{
${ }^{2}$ The education system in Ecuador is divided into three main parts: pre-primary education, elementary and secondary education (mandatory and named Educación General Básica EGB), and higher education (named Bachillerato General Unificado BGU). Children have to legally attend primary and secondary education EGB which runs from about 6 years old until the student is 14 years old. Besides, there are vocational education schools designed to provide technical skills required to perform a specific job.
} 
How to cite: Alvarado, L. E., Aragón, R. R. \& Bretones, F. D. (2020). Teachers' Attitudes Towards the Introduction of ICT in Ecuadorian Public Schools. TechTrends, 64. doi: 10.1007/s11528-020-00483-7.

\begin{tabular}{|c|c|c|c|}
\hline 16 & Man & Secondary teacher & Julio Estrada Icaza \\
\hline 17 & Man & Elementary teacher & Manuela León Guamán \\
\hline 18 & Man & Secondary teacher & Luis Félix López \\
\hline 19 & Woman & Secondary teacher & Juan Javier Espinoza \\
\hline 20 & Man & Secondary teacher & Liliam Rugel de Bermúdez \\
\hline 21 & Woman & Secondary teacher & Francisco García Avilés \\
\hline 22 & Man & Elementary teacher & 13 de marzo \\
\hline 23 & Man & Elementary teacher & Pedro Vicente Maldonado \\
\hline 24 & Woman & Secondary teacher & Futuro del saber \\
\hline 25 & Woman & Secondary teacher & Vicente Rocafuerte \\
\hline 26 & Woman & Secondary teacher & Violeta Luna Carrera \\
\hline 27 & Woman & Elementary teacher & Maritza Thalia Alban \\
\hline 28 & Woman & Elementary teacher & Jose Marti \\
\hline 29 & Woman & Secondary teacher & Lcda. Clara león de Posligua \\
\hline 30 & Woman & Secondary teacher & Fermín Vera Rojas \\
\hline 31 & Woman & Elementary teacher & José María Urbina \\
\hline 32 & Woman & Elementary teacher & Mayor Ignacio Viteri \\
\hline 33 & Woman & Secondary teacher & Transito Amaguaña \\
\hline 34 & Woman & Elementary teacher & América \\
\hline 35 & Woman & Elementary teacher & Agustín Guerrero \\
\hline 36 & Man & Secondary teacher & Jaime Roldos Aguilera \\
\hline 37 & Woman & Secondary teacher & Río Marañón \\
\hline 38 & Woman & Secondary teacher & Fermín Vera Rojas \\
\hline 39 & Man & Secondary teacher & Fernando Daquilema \\
\hline 40 & Woman & Secondary teacher & Rumiñahui \\
\hline 41 & Woman & Elementary teacher & Blanca García plaza de Arias \\
\hline 42 & Man & Vocational teacher & Eugenio espejo \\
\hline 43 & Woman & Secondary teacher & José Martinez Queirolo \\
\hline 44 & Woman & Elementary teacher & Estados Unidos \\
\hline 45 & Woman & Elementary teacher & Rommel Mosquera Jurado \\
\hline 46 & Man E & ntary teacher Aleja & idro Carrión Aguirre \\
\hline 47 & Man & Secondary teacher & 26 de noviembre \\
\hline 48 & Woman & Elementary teacher & Humberto More \\
\hline 49 & Man & Elementary teacher & Francisco Zevallos Reyre \\
\hline 50 & Woman & Secondary teacher & Dolores Veintimilla \\
\hline 51 & Woman & Elementary teacher & Ignacio Viteri Mosquera \\
\hline 52 & Man & Elementary teacher & Eduardo Kingman \\
\hline 53 & Man & Elementary teacher & Enrique Gil Calderón \\
\hline 54 & Woman & Elementary teacher & Jose Joaquín de Olmedo \\
\hline 55 & Man & Elementary teacher & Adalberto Ortiz Quiñones \\
\hline 56 & Woman & Elementary teacher & Isabela Herrería \\
\hline
\end{tabular}

All the subjects participated voluntarily in the interviews, following the rules of the Helsinki

Declaration and with no financial reward. 
How to cite: Alvarado, L. E., Aragón, R. R. \& Bretones, F. D. (2020). Teachers' Attitudes Towards the Introduction of ICT in Ecuadorian Public Schools. TechTrends, 64. doi: 10.1007/s11528-020-00483-7.

The inclusion criteria for participation in this study were those of being currently working as a teacher and having a minimum of three-year teaching experience. All teachers interviewed were Ecuadorians.

Moreover, the collection of information was based on a very open and little-directive approach, although a very brief outline of semistructured questions was taken as a starting point.

The interview protocol was structured so that, after a short explanation of the study, participants were required to give their written consent to participate in the study. Participants were informed about the objectives of the study and the possibility of withdrawing at any time or omitting any part of the discussion. All interviews were conducted from September to December 2018 and performed in Spanish. The average length of interview was 52:35 minutes.

All the recorded material was transcribed literally. A content analysis (van Dijk 1985) was performed with the collected information using the qualitative analysis program NVivo@ $\mathrm{v}$. 11, conducting an iterative and inductive text analysis (Schreier 2014) for its subsequent structuration according to the model proposed by Gioia, Corley, \& Hamilton (2013). Thus, specifically, based on the transcription of the textual interviews, the participants' stories were segmented and coded according to topics and then classified into categories. In this process of analysis and coding, at least two researchers of the study have participated in order to increase the validity of results.

In order to measure similarity and dissimilarity of these second-order variables, the Jaccard's similarity coefficient $(J)$ was used (Steinbach, Tan, Xiong \& Kumar 2007), which analyzes the co-occurrence without considering the frequency of occurrence of such terms. The coefficient is given by $a /(a+b+c)$, where $a$ represents the number of cases where two terms, $a$ 
How to cite: Alvarado, L. E., Aragón, R. R. \& Bretones, F. D. (2020). Teachers' Attitudes Towards the Introduction of ICT in Ecuadorian Public Schools. TechTrends, 64. doi: 10.1007/s11528-020-00483-7.

and $b$, concur; where $b$ represents the cases where the term $a$ appears but not the term $b$; and where $c$ represents the number of cases where the term $b$ appears but not the term $a$, where cooccurences and non co-occurrences are considered similarily. Thus, the terms are clustered so that two terms will be closer if they appear together in the same case, building a cluster diagram. This coefficient varies between 0 and 1, being higher the relationship between variables when this coefficient tends to 1 .

\section{Results}

After having analyzed the content of each interview according to the proposed methodology, we observed four second-order variables related to the introduction of ICT in schools: lack and inequality of job resources; pressure and high demands; organizational demands, and; fear and personal insecurity (see Figure 1). These variables relate to each other creating situations of stress and discomfort towards technology in teachers which affects their physical and psychological health. 
How to cite: Alvarado, L. E., Aragón, R. R. \& Bretones, F. D. (2020). Teachers' Attitudes Towards the Introduction of ICT in Ecuadorian Public Schools. TechTrends, 64. doi: 10.1007/s11528-020-00483-7.

Figure 1: Concepts, variables and aggregate dimension of the study

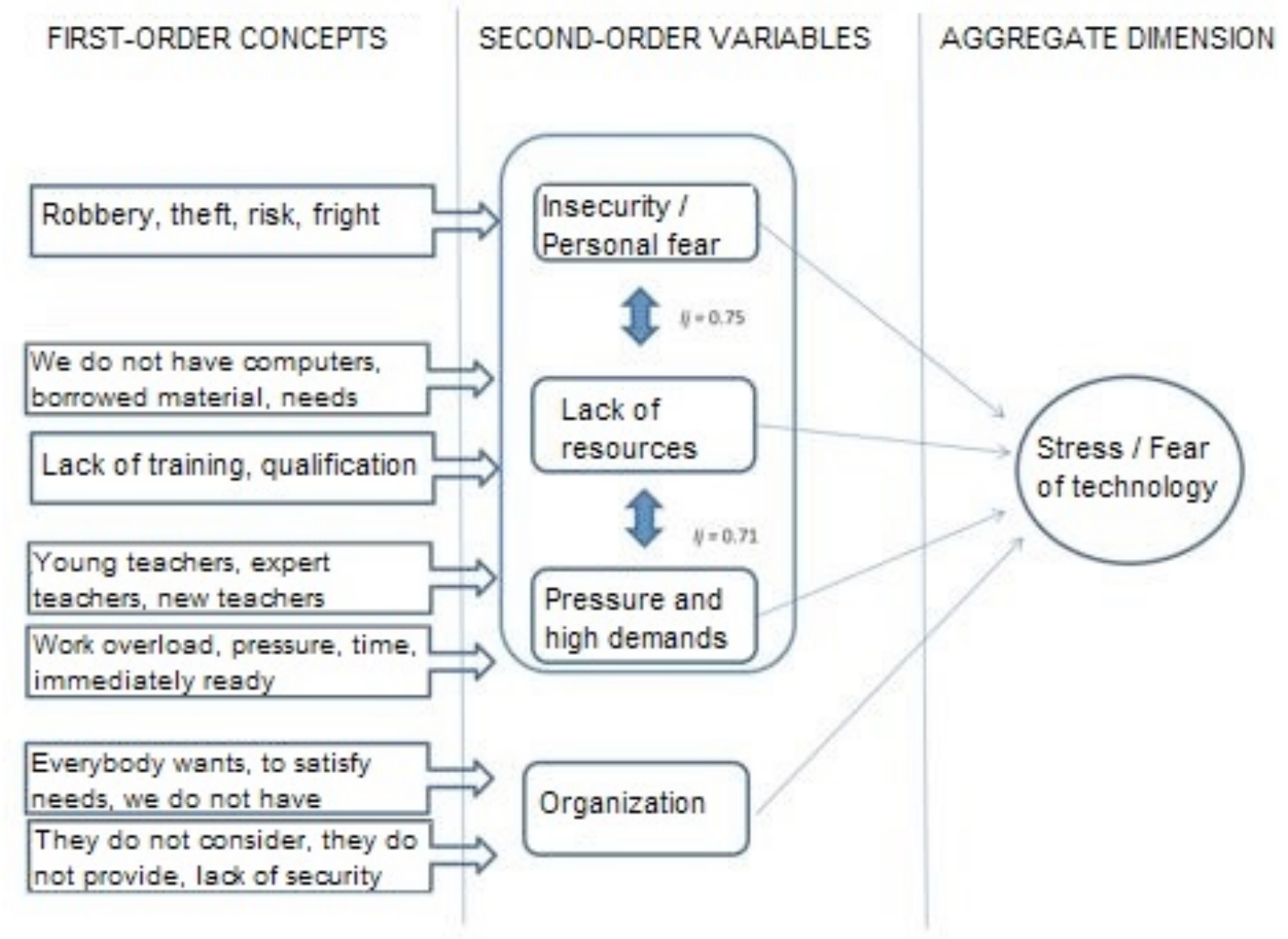

Every variable is further detailed below.

\subsection{Lack and Inequality of Job Resources}

One of the most referenced variables by participants has been the lack of available job resources.

In this sense, teachers acknowledged the availability of resources in some schools named Millennium, Governmental educational units implemented since 2009 and built with the highest quality infrastructure in order to achieve high-quality and inclusive education (Aruch, Loja, \& Sanders 2014) on which the Government focused its investment efforts: 
How to cite: Alvarado, L. E., Aragón, R. R. \& Bretones, F. D. (2020). Teachers' Attitudes Towards the Introduction of ICT in Ecuadorian Public Schools. TechTrends, 64. doi: 10.1007/s11528-020-00483-7.

...' the positive side of this, the Government has implemented the Millennium School, which has a complete infrastructure' (Participant 16).

However, there is a widespread perception that this investment has been made unequally and unfairly. In fact, most teachers confirmed that they did not benefit from the logistic support program that the Government offered to some schools in a limited way so teachers had to make up for this lack of resources with personal resources:

... 'we do not have computers there, the institution does not have, and we bring ours' (Participant 48).

This inequality between schools generates a feeling of organizational injustice in most participants.

... I know that there are millennium schools that have everything, but they do not worry about us, many of us do not even have an establishment, the establishment is borrowed, a borrowed school, and we teachers do our best to work here [...] I do not have a computer at school, in April I will have been 2 years without one, imagine how my work is! What I have to do then is taking mine to school' (Participant 2).

Teachers also mentioned the lack of previous knowledge or training to face and adapt to these technological changes:

... 'it is true that now we teachers have many opportunities to attend seminars, right? But as I said before, we should have been trained for this technology stuff, definitely' (Participant 54).

In short, teachers reported a poor and unequal allocation of resources, not only physical and technological, but also personal and cognitive, that represent levels of dependency affecting the quality of relationships and the self-concept of their work performance: 
How to cite: Alvarado, L. E., Aragón, R. R. \& Bretones, F. D. (2020). Teachers' Attitudes Towards the Introduction of ICT in Ecuadorian Public Schools. TechTrends, 64. doi: 10.1007/s11528-020-00483-7.

...' 'yesterday my workmate had to stay late and ask another colleague for help because he does not know [...] I have workmates that have to pay somebody else to get their work done because they do not know how to use the computer' (Participant 33).

\subsection{Pressure and High Demands}

Besides that unequal allocation of resources, most participants expressed the pressure they perceived from the own educational institution in order to implement digital elements in their teaching activity.

Teachers reported changes in the way of approaching their work with frequent interruptions and changes in the pace of work that affected their teaching performance:

... 'they only impose on us, they impose on us what we have to do and all those things, [...] at the most unexpected moment we are asked for things, information, and we have to stop grading to start to do things on the computer. Then, we are living under pressure, (Participant 24).

... 'you are sent an email 'I want this right now', you are sent some information at twelve and that email must be ready by one o'clock. And it is not a simple piece of information, you have to fill it in, they are matrices... We feel pressure in that sense too' (Participant 55).

Not only does this pressure come from the institution, teachers also perceive social pressure from students, which places teachers in a disadvantaged position.

... 'the same pressure pushes us to train ourselves too because, as the colleague said, we are in a digital age where kids are born and already know' (Participant 5).

... 'nowadays everybody has to be immersed in this, whether we want it or not, this is how it has to work now' (Participant 56). 
How to cite: Alvarado, L. E., Aragón, R. R. \& Bretones, F. D. (2020). Teachers' Attitudes Towards the Introduction of ICT in Ecuadorian Public Schools. TechTrends, 64. doi: 10.1007/s11528-020-00483-7.

In addition, technology is perceived as a supervision element even from students, who can use it to record lessons, which makes teachers fear future consequences.

... 'they can be recording us, filming us, and we cannot say anything' (Participant 19).

\subsection{Organizational Demands}

However, all these demands are perceived with concern due to their potential influence on teachers' perfomance and professional career. In this sense, there is a fear of supervision and technological underqualification as well as a feeling of imbalance between the expected skills for the job and the level people think they possess.

... 'no matter how hard you want to work, we know our subject, we master the subject but there is a person behind us and we do not know if they are grading us, if they are seeing our mistakes, then...we feel pressure in this sense too' (Participant 18).

On the other hand, this pressure increases because younger teachers have more computer skills and hold positions of greater organizational responsibility so older teachers fear competition with younger teachers and worry about their underqualification when compared to theirs.

... 'key positions are held by young people, without work experience but with experience in the use of technology, so they have an advantage' (Participant 4).

\subsection{Fear and Personal Insecurity}

Finally, along with these high demands and fear of technological change, all participants reported that, as a result of the unexpected implementation of ICT in schools, they had experienced feelings of fear and personal insecurity caused by the digitalization of schools. 
How to cite: Alvarado, L. E., Aragón, R. R. \& Bretones, F. D. (2020). Teachers' Attitudes Towards the Introduction of ICT in Ecuadorian Public Schools. TechTrends, 64. doi: 10.1007/s11528-020-00483-7.

Since their schools are located in disadvantaged neighbourhoods affected by crime, and in order to avoid thefts of computers inside schools, teachers must take computers to their houses daily, so their feeling of fear increases and worsens because that sense of insecurity not only appears at the school but also on their way to and from their workplaces. Personal insecurity experienced by teachers is clearly present in their comments.

... 'we realize that people lie in wait to steal something from you, that is why they are waiting for teachers to leave' (Participant 10).

Threat of theft not only involves the loss of your computer but also the loss of the information stored in computers as well as the obligation to pay for the stolen computer.

... 'all the information is there, what are we left with? A debt of 700 dollars' (Participant 45).

These four variables generate high levels of stress and insecurity on the participating teachers. But do they act independently or is there any relationship between them?

By applying the Jaccard's similarity coefficient $(J)$, we observed a strong relationship, as shown in Figure 2. Specifically, those variables with greater coincidences were the variables 'lack of job resources' and 'fear and personal insecurity', with a high coefficient between them $(J=, 75)$.

The relationship of the variable 'lack of resources' with 'high demands' was also high $(J=$ ,71) unlike with the variable 'organization' $(J=, 42)$.

As for the variable 'fear and insecurity', this had moderate indices of similarity with the variables 'pressure and high demands' $(J=.50)$ and 'organization' $(J=.42)$. 
How to cite: Alvarado, L. E., Aragón, R. R. \& Bretones, F. D. (2020). Teachers' Attitudes Towards the Introduction of ICT in Ecuadorian Public Schools. TechTrends, 64. doi: 10.1007/s1 1528-020-00483-7.

Figure 2: Relationships and Jaccard index $(I j)$ of the study variables

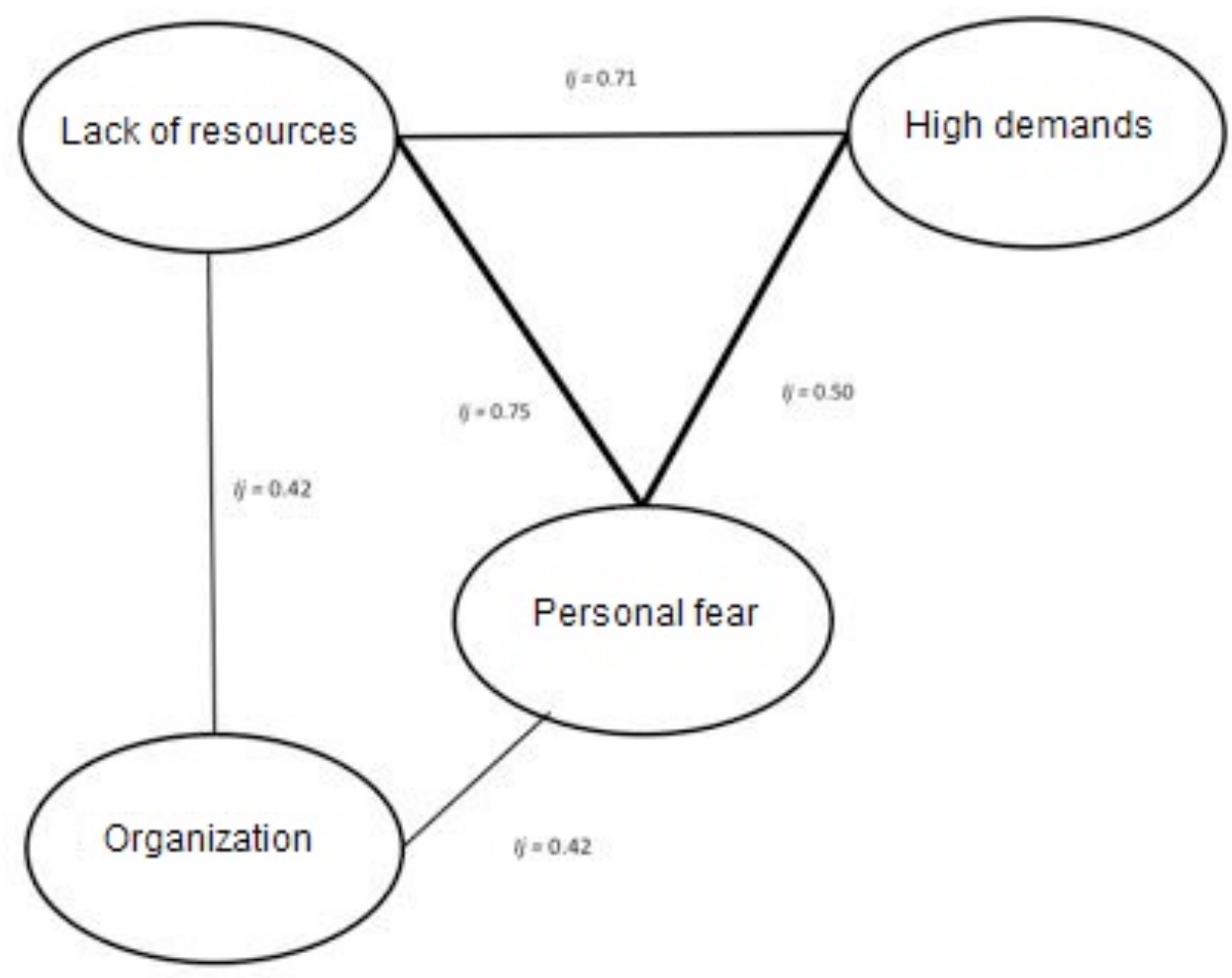

\section{Discussion}

From the analysis of the results described above we can draw some conclusions from our study.

Firstly, the lack of available resources is one of the most common sources of discomfort towards the use of technology among the participating teachers. Thus, regarding the introduction of ICT in schools, teachers reported an unequal allocation of resources along with high job and emotional demands and pressure. All this involves discomfort and damages psychological and physical resources of employees leading to exhaustion.

This lack of resources not only refers to certain instrumental aspects but, according to the theory of Bakker \& Demerouti (2014), other psychological, organizational or social aspects of 
How to cite: Alvarado, L. E., Aragón, R. R. \& Bretones, F. D. (2020). Teachers' Attitudes Towards the Introduction of ICT in Ecuadorian Public Schools. TechTrends, 64. doi: 10.1007/s11528-020-00483-7.

work should be taken into account since they contribute to this absence of pleasant feelings, hinder personal growth, learning and development, and have a negative impact on some organizational variables such as job satisfaction, motivation or engagement, specially on teachers (Bakker, Hakanen, Demerouti, \& Xanthopoulou 2007; Hakanen, Bakker, \& Schaufeli 2006).

In this sense, there is a boomerang effect in the implementation of the use of computers in schools because, although the Government has made an investment in technology, its allocation has been unequal, causing grievances when comparing between schools. Therefore, the need is generated but resources are not offered to all teachers, so some of them have to provide their own resources to schools (their personal computers) in order to satisfy these created needs.

Moreover, this lack of resources is associated with organizational problems and the perception of organizational injustice due to the lack of equity that becomes clear when comparing the unequal availability of job resources between schools (Cohen-Charash \& Spector 2001; Livingstone 2012; Moorman 1991).

On the other hand, there is a clear lack of teachers' participation in the school digitalization process as well as an obvious absence of technological, cognitive and emotional training and knowledge towards the new implemented change.

However, the negative consequences of this lack of resources not only appears at the organizational level. Teachers perceive high organizational and social demands regarding the digitalization of their teaching activity as well as few technological skills in comparison with those of students, which results in low levels of self-concept in teachers, affecting their rejection and non-implementation of ICT in their teaching-learning activities (Lawrence \& $\operatorname{Tar} 2018)$ 
How to cite: Alvarado, L. E., Aragón, R. R. \& Bretones, F. D. (2020). Teachers' Attitudes Towards the Introduction of ICT in Ecuadorian Public Schools. TechTrends, 64. doi: 10.1007/s11528-020-00483-7.

Thus, teachers have to 'compete' with more technologically qualified young teachers (Guo, Dobson, \& Petrina 2008; Orlando 2014). These younger teachers not only have more computer skills but they are also perceived by older teachers as a new supervision element of their activity, affecting their performance in class and their self-concept as teachers.

Basically, in our study we have observed that, when introducing ICT in schools, teachers reported that this process produced some feelings of insecurity and stress. For teachers, this insecurity and fear stemmed from different sources. On the one hand, from supervisors and constant evaluation processes. On the other hand, from the pressure and competition with other younger colleagues, which may affect traditional career development processes based on seniority and experience in teaching. Finally, from students, who are another source of insecurity in contrast to their perception of experts and the fear that students question them or their teaching skills.

Therefore, the introduction of ICT in schools is perceived in many cases as a threat to their work self-esteem as teachers, which may produce feelings of fear or rejection, in line with the findings of other authors (Celik \& Yesilyurt 2013). In addition, teachers report the lack of resources, not only physical or psychological, but mainly personal and cognitive, when dealing with these changes, although the circumstances may vary, and in turn the personenvironment relationships, and produce different emotions, in line with the findings of other authors (Saunders 2013; Wilfong 2006).

\section{Conclusions}

In conclusion, we believe that the introduction of ICT in schools is very useful as they improve teaching-learning processes and encourage the development of students in technological environments. 
How to cite: Alvarado, L. E., Aragón, R. R. \& Bretones, F. D. (2020). Teachers' Attitudes Towards the Introduction of ICT in Ecuadorian Public Schools. TechTrends, 64. doi: 10.1007/s11528-020-00483-7.

That is the reason why any process of change in schools should be planned and include social and emotional processes of teachers in order to minimize rejections and fear of the self-image of the teaching role (Bahia, Freire, Estrela, Amaral, \& Espírito Santo 2017). Thus, when designing the implementation of technological processes in schools, the relational, motivational and cognitive factors should be considered according to the Lazarus' theory of emotion (1991).

Therefore, we believe that, when implementing such processes, teachers' engagement should be considered from the beginning, since they are the main agents of the implementation. Mainly, such engagement should involve affective and attitudinal aspects towards the introduction of technological environments in schools.

Investing in goods and equipment is useless, especially in developing countries where resources are scarce, if this is not accompanied by previous actions, not only technical training but also awareness-raising.

On the other hand, although we are immersed in quick processes of globalization, any educational change should take into consideration cultural and local aspects of the environment where it is intended to be implemented so that, although technological developments are global, we should consider local and cultural aspects in its design and implementation. Thus, in our case of study, other criteria such as personal security and violence should be taken into account before designing the digitalization process.

In addition, and more especially in the absence of resources in developing countries, the fact of focusing all investment in a few schools at the expense of the rest causes inequity that do not help embrace the change that is intended to be implemented, but quite the opposite. Probably, a better allocation of resources and, mainly, greater clarity in the distribution criteria may minimize those negative effects. 
How to cite: Alvarado, L. E., Aragón, R. R. \& Bretones, F. D. (2020). Teachers' Attitudes Towards the Introduction of ICT in Ecuadorian Public Schools. TechTrends, 64. doi: 10.1007/s11528-020-00483-7.

Finally, we consider that it is advisable to further study the perceptions and fears of digitalization in every stage of the educational systems, especially in lower levels and in developing countries, in order to improve access to all technological contexts in a more equitable, inclusive and socially sustainable way.

\section{6.-References}

Addas, S., \& Pinsonneault, A. (2015). The many faces of information technology interruptions: A taxonomy and preliminary investigation of their performance effects. Information Systems Journal, 25(3), 231-273. http://doi.org/10.1111/isj.12064

Al-fudail, M., \& Mellar, H. (2008). Investigating teacher stress when using technology. $\begin{array}{llll}\text { Computer } \quad \& \quad \text { Education, } & \text { 51(3), }\end{array}$ http://doi.org/10.1016/j.compedu.2007.11.004

Aruch, M., Loja, A., \& Sanders, J. B. (2014). Social Entrepreneurship and Information and Communication Technologies in Ecuador: Examples and Opportunities. In A.W. Wiseman (ed.) International Educational Innovation and Public Sector Entrepreneurship (pp.157-190). Bingley, UK: Emerald.

Bahia, S., Freire, I. P., Estrela, M. T., Amaral, A., \& Espírito Santo, J. A. (2017). The Bologna process and the search for excellence: between rhetoric and reality, the emotional reactions of teachers. Teaching in Higher Education, 22(4), 467-482. http://doi.org/10.1080/13562517.2017.1303471

Bakker, A. B., \& Demerouti, E. (2014). Job Demands-Resources Theory/Work and Wellbeing: Wellbeing: A Complete Reference Guide. Volume III. John Wiley \& Sons, Ltd. https://doi.org/10.1002/9781118539415.wbwell019

Bakker, A. B., Hakanen, J. J., Demerouti, E., \& Xanthopoulou, D. (2007). Job resources boost work engagement, particularly when job demands are high. Journal of Educational 
How to cite: Alvarado, L. E., Aragón, R. R. \& Bretones, F. D. (2020). Teachers' Attitudes Towards the Introduction of ICT in Ecuadorian Public Schools. TechTrends, 64. doi: 10.1007/s11528-020-00483-7.

Psychology, 99(2), 274-284. http://doi.org/10.1037/0022-0663.99.2.274

Ballet, K., \& Kelchtermans, G. (2008). Workload and willingness to change: Disentangling the experience of intensification. Journal of Curriculum Studies, 40(1), 47-67. http://doi.org/10.1080/00220270701516463

Barak, M. (2016). Science Teacher Education in the Twenty-First Century: a Pedagogical Framework for Technology-Integrated Social Constructivism. Research in Science Education, 47(2), 283-303. http://doi.org/10.1007/s11165-015-9501-y

Bretones, F. D., González-González, J. M., Francés-Gómez, P. \& González, R. (2017). El impacto de las tecnologías como nuevo riesgo psicosocial en el trabajo. In C. Palma y M. González y (Eds.), El riesgo tecnológico: impactos sociales (pp. 107-123). Madrid: Catarata.

Buckley, J., Seery, N., Canty, D., \& Gumaelius, L. (2018). Visualization, inductive reasoning, and memory span as components of fluid intelligence: Implications for technology education. International Journal of Educational Research, 90(May), 64-77. https://doi.org/10.1016/j.ijer.2018.05.007

Celik, V., \& Yesilyurt, E. (2013). Attitudes to technology, perceived computer self-efficacy and computer anxiety as predictors of computer supported education. Computers and Education, 60(1), 148-158. http://doi.org/10.1016/j.compedu.2012.06.008

Chesley, N. (2014). Information and communication technology use, work intensification and employee strain and distress. Work, Employment \& Society, 28(4), 589-610. http://doi.org/10.1177/0950017013500112

Cohen-Charash, Y., \& Spector, P. E. (2001). The Role of Justice in Organizations: A MetaAnalysis. Organizational Behavior and Human Decision Processes, 86(2), 278-321. http://doi.org/10.1006/obhd.2001.2958

Currie, J., \& Eveline, J. (2011). E-technology and work/life balance for academics with young 
How to cite: Alvarado, L. E., Aragón, R. R. \& Bretones, F. D. (2020). Teachers' Attitudes Towards the Introduction of ICT in Ecuadorian Public Schools. TechTrends, 64. doi: 10.1007/s11528-020-00483-7.

children. Higher Education, 62(4), 533-550. http://doi.org/10.1007/s10734-010-9404-9

Ertmer, P. A., Ottenbreit-Leftwich, A. T., Sadik, O., Sendurur, E., \& Sendurur, P. (2012). Teacher beliefs and technology integration practices: A critical relationship. Computers and Education, 59(2), 423-435. http://doi.org/10.1016/j.compedu.2012.02.001

Eubanks, V. (2007). Popular technology: Exploring inequality in the information economy. Science and Public Policy, 34(2), 127-138. http://doi.org/10.3152/030234207X193592

Fernández-Cruz, F. J., \& Fernández-Díaz, M. J. (2016). Los docentes de la Generación Z y sus competencias digitales[Generation Z's Teachers and their Digital Skills].Revista Comunicar, 24(46), 97-105. http://doi.org/10.3916/C46-2016-10

Gioia, D. A., Corley, K. G., \& Hamilton, A. L. (2013). Seeking Qualitative Rigor in Inductive Research: Notes on the Gioia Methodology. Organizational Research Methods, 16(1), 15-31. http://doi.org/10.1177/1094428112452151

González-Sanmamed, M., Sangrà, A., \& Muñoz-Carril, P. C. (2017). We can, we know how. But do we want to? Teaching attitudes towards ICT based on the level of technology integration in schools. Technology, Pedagogy and Education, 26(5), 633-647. http://doi.org/10.1080/1475939X.2017.1313775

Guo, R. X., Dobson, T., \& Petrina, S. (2008). Digital Natives, Digital Immigrants: An Analysis of Age and Ict Competency in Teacher Education. Journal of Educational Computing Research, 38(3), 235-254. http://doi.org/10.2190/EC.38.3.a

Hakanen, J. J., Bakker, A. B., \& Schaufeli, W. B. (2006). Burnout and work engagement among teachers. Journal of School Psychology, 43(6), 495-513. http://doi.org/10.1016/j.jsp.2005.11.001

Harris, K. J., Harris, R. B., Carlson, J. R., \& Carlson, D. S. (2015). Resource loss from technology overload and its impact on work-family conflict: Can leaders help? Computers in Human Behavior, 50, 411-417. http://doi.org/10.1016/j.chb.2015.04.023 
How to cite: Alvarado, L. E., Aragón, R. R. \& Bretones, F. D. (2020). Teachers' Attitudes Towards the Introduction of ICT in Ecuadorian Public Schools. TechTrends, 64. doi: 10.1007/s1 1528-020-00483-7.

Hammersley, M. (2000). The Relevance of Qualitative Research. Oxford Review of Education, 26(3-4), 393-405. https://doi.org/10.1080/713688545

Jena, R. K. (2015). Technostress in ICT enabled collaborative learning environment: An empirical study among Indian academician. Computers in Human Behavior, 51, 11161123. http://doi.org/10.1016/j.chb.2015.03.020

Joo, Y. J., Lim, K. Y., \& Kim, N. H. (2016). The effects of secondary teachers' technostress on the intention to use technology in South Korea. Computers \& Education, 95, 114122. http://doi.org/10.1016/j.compedu.2015.12.004

Kopcha, T. J. (2012). Teachers' perceptions of the barriers to technology integration and practices with technology under situated professional development. Computers \& Education, 59(4), 1109-1121. http://doi.org/10.1016/j.compedu.2012.05.014

Kotrlik, J. W., \& Redmann, D. H. (2005). Extent of Technology Integration in Instruction by Adult Basic Education Teachers. Adult Education Quarterly, 55(3), 200-219. http://doi.org/10.1177/0741713605274630

Lawrence, J. E., \& Tar, U. A. (2018). Factors that influence teachers' adoption and integration of ICT in teaching/ learning process. Educational Media International, 55(1), 79-105. http://doi.org/10.1080/09523987.2018.1439712

Lazarus, R. S. (1991). Progress on a cognitive-motivational-relational theory of emotion. American Psychologist, 46(8), 819-834. http://doi.org/10.1037/0003-066X.46.8.819

Leonard, L. J. (2001). From indignation to indifference: Teacher concerns about externally imposed classroom interruptions. Journal of Educational Research, 95(2), 103-109. http://doi.org/10.1080/00220670109596578

Lindqvist, P., \& Nordanger, U. K. (2006). Who dares to disconnect in the age of uncertainty? Teachers' recesses and 'off-the-clock' work. Teachers and Teaching: Theory and Practice, 12(6), 623-637. http://doi.org/10.1080/13540600601029637 
How to cite: Alvarado, L. E., Aragón, R. R. \& Bretones, F. D. (2020). Teachers' Attitudes Towards the Introduction of ICT in Ecuadorian Public Schools. TechTrends, 64. doi: 10.1007/s11528-020-00483-7.

Livingstone, S. (2012). Critical reflections on the benefits of ICT in education. Oxford Review of Education, 38(1), 9-24. http://doi.org/10.1080/03054985.2011.577938

Martin, S., Diaz, G., Sancristobal, E., Gil, R., Castro, M., \& Peire, J. (2011). New technology trends in education: Seven years of forecasts and convergence. Computers \& Education, 57(3), 1893-1906. http://doi.org/10.1016/j.compedu.2011.04.003

Moorman, R. H. (1991). Relationship between organizational justice and organizational citizenship behaviors: Do fairness perceptions influence employee citizenship? Journal of Applied Psychology, 76(6), 845-855. http://doi.org/10.1037/0021-9010.76.6.845

Orlando, J. (2014). Veteran teachers and technology: Change fatigue and knowledge insecurity influence practice. Teachers and Teaching: Theory and Practice, 20(4), 427439. https://doi.org/10.1080/13540602.2014.881644

Ottenbreit-Leftwich, A. T., Glazewski, K. D., Newby, T. J., \& Ertmer, P. A. (2010). Teacher value beliefs associated with using technology: Addressing professional and student needs. Computers \& Education, 55(3), 1321-1335. http://doi.org/10.1016/j.compedu.2010.06.002

Otterborn, A., Schönborn, K., \& Hultén, M. (2018). Surveying preschool teachers' use of digital tablets: general and technology education related findings. International Journal of Technology and Design Education, 29(4), 717-737. http://doi.org/10.1007/s10798018-9469-9

Paraskeva, F., Bouta, H., \& Papagianni, A. (2008). Individual characteristics and computer self-efficacy in secondary education teachers to integrate technology in educational practice. Computers \& Education, 50(3), 1084-1091. http://doi.org/10.1016/j.compedu.2006.10.006

Perrotta, C. (2017). Beyond rational choice: How teacher engagement with technology is mediated by culture and emotions. Education and Information Technologies, 22(3), 789- 
How to cite: Alvarado, L. E., Aragón, R. R. \& Bretones, F. D. (2020). Teachers' Attitudes Towards the Introduction of ICT in Ecuadorian Public Schools. TechTrends, 64. doi: 10.1007/s11528-020-00483-7.

804. http://doi.org/10.1007/s10639-015-9457-6

Ragu-Nathan, T. S., Tarafdar, M., Ragu-Nathan, B. S., \& Tu, Q. (2008). The consequences of technostress for end users in organizations: Conceptual development and validation. Information Systems Research, 19(4), 417-433. http://doi.org/10.1287/isre.1070.0165

Rosen, L. D., \& Weil, M. M. (1995). Computer availability, computer experience and technophobia among public school teachers. Computers in Human Behavior, 11(1), 931. http://doi.org/10.1016/0747-5632(94)00018-D

Saunders, R. (2013). The role of teacher emotions in change: Experiences, patterns and implications for professional development. Journal of Educational Change, 14(3), 303333. http://doi.org/10.1007/s10833-012-9195-0

Schreier, M. (2014). Qualitative content analysis. In U. Flick (Ed.), The SAGE handbook of qualitative data analysis (pp. 170-183). London, UK: SAGE https://doi.org/10.4135/9781446282243.n12

Selwyn, N. (2010). Looking beyond learning: Notes towards the critical study of educational technology. Journal of Computer Assisted Learning, 26(1), 65-73. http://doi.org/10.1111/j.1365-2729.2009.00338.x

Shaw, I. (2003). Qualitative research and outcomes in health, social work and education. Qualitative Research, 3(1), 57-77.

Steinbach, M., Tan, P. N., Xiong, H., \& Kumar, V. (2007). Objective measures for association pattern analysis. Contemporary Mathematics, 443, 205-226.

Tarafdar, M., Tu, Q., Ragu-Nathan, B., \& Ragu-Nathan, T. (2007).The impact of technostress on role stress and productivity. Journal of Management Information Systems, 24(1), 301-328. http://doi.org/10.2753/MIS0742-1222240109

Tondeur, J., van Braak, J., Ertmer, P. A., \& Ottenbreit-Leftwich, A. (2016). Understanding the relationship between teachers's pedagogical beliefs and technology use in education: 
How to cite: Alvarado, L. E., Aragón, R. R. \& Bretones, F. D. (2020). Teachers' Attitudes Towards the Introduction of ICT in Ecuadorian Public Schools. TechTrends, 64. doi: 10.1007/s1 1528-020-00483-7.

a systematic review of qualitative evidence. Educational Technology Research and Development, 65(3), 555-575. http://doi.org/10.1007/s11423-016-9481-2

Torraco, R. (2018). Economic Inequality, Educational Inequity, and Reduced Career Opportunity: A Self-perpetuating Cycle? New Horizons in Adult Education and Human Resource Development, 30(1), 19-29. http://doi.org/10.1002/nha3.20206

Tsang, K. K., \& Kwong, T. L. (2017). Teachers' emotions in the context of education reform: labor process theory and social constructionism. British Journal of Sociology of Education, 38(6), 841-855. http://doi.org/10.1080/01425692.2016.1182007

Van Dijk, T. A. (1985). Semantic discourse analysis. Handbook of discourse analysis, 2, 103136

Wajcman, J., \& Rose, E. (2011). Constant connectivity: rethinking interruptions at work. Organization Studies, 32(7), 941-961. http://doi.org/10.1177/0170840611410829

Wilfong, J. D. (2006). Computer anxiety and anger: the impact of computer use, computer experience, and self-efficacy beliefs. Computers in Human Behavior, 22(6), 1001-1011. http://doi.org/10.1016/j.chb.2004.03.020

Yu, T.-K., Lin, M.-L., \& Liao, Y.-K. (2017). Understanding factors influencing information communication technology adoption behavior: The moderators of information literacy and digital skills. Computers in Human Behavior, 71, 196-208. http://dx.doi.org/10.1016/j.chb.2017.02.005 